\title{
THE IMPACT OF WASTE INCINERATION ON HUMAN BEINGS AND THE ENVIRONMENT
}

\author{
ODDZIAŁYWANIE SPALARNI ODPADÓW NA LUDZI I ŚRODOWISKO
}

\begin{abstract}
The article discusses issues related to the impact of incineration on human health and the environment. The aim of the work is to make a broad overview of the existing literature in this area. The problem was described in the literature based on a number of waste incineration plants studies in both Europe and all around the world. Subjects analyzed in the literature were risks at workplace, both administrative ones and directly related to the process of thermal treatment of waste. These risks result among others from the atmospheric emissions of many pollutants, including most of all polychlorinated dibenzo-p-dioxins and polychlorinated dibenzofurans, heavy metals and some volatile organic compounds. The results of these studies will be an important argument in the discussion on the possible risks to humans and the environment posed by waste incineration plants and the expediency of building waste incinerators in Poland.
\end{abstract}

Keywords: waste incineration, waste-to energy, environmental impact, occupational safety and health

\section{Introduction}

Polish integration with the European Union requires us to adapt to the legal requirements in almost every area of the economy. The integration process was started long before the Polish accession to the European Union, and formally ended at the moment of accession in 2004, although the implementation of new directives into Polish law is a continuous process. An area where there are still significant differences between the EU countries and Poland as well as the greatest time lag is environmental protection, in particular waste management.

At present we are in the process of remodeling the entire waste management system, which results from the need to meet the European requirements. Despite the fact that, according to Eurostat, a statistical Pole produces much less municipal waste than an average citizen of the EU (respectively Poland - $300 \mathrm{~kg} /$ year/inhabitant, European Union $500 \mathrm{~kg} /$ year/inhabitant) - there is still a lot of work for us in this regard. Up till now in Poland in fact the only method of dealing with waste has been landfilling. We are obliged to change this situation by obtaining the appropriate level of recovery, recycling and by

\footnotetext{
${ }^{1}$ Lodz University of Technology, ul. Wólczańska 175, 90-924 Łódź, Poland, phone +48 426313795 , fax +48 4263681 33, email: 800439@edu.p.lodz.pl

*Corresponding author: grzegorz.wielgosinski@p.lodz.pl
} 
reducing waste generation. Reduction of the waste landfill is inseparably connected with the necessity of its thermal treatment, in particular the waste which can neither be recovered nor recycled. Thermal processing is also a method of energy recovery from generated waste, which is one of the measures of waste handling according to Directive 2008/98/EC [1].

Plans to build waste incineration plants are accompanied by a huge public controversy, protests, usually not supported by rational arguments. The purpose of this paper is to review the existing literature on currently operating waste incineration facilities in Europe and in the world, with special emphasis on the impact of studied facilities on the people employed in them and the people living in the immediate surroundings as well as the impact on the environment. In this article, based on our extensive review of the literature, we presented the actual impact of a waste incineration process and accompanying atmospheric emissions of harmful agents on people and the environment in the vicinity of the investment.

\section{Hazards associated with the process of waste incineration}

Pollutants generated in waste incineration plants, as by-products of the thermal process, are the main argument for opponents of the construction of these facilities. These are mainly heavy metals: dioxins (polychlorinated dibenzo-p-dioxins and polychlorinated dibenzofurans - PCDD/Fs), polycyclic aromatic hydrocarbons, polychlorinated biphenyls and various volatile organic compounds.

Table 1 shows a summary of the main chemical pollutants in the context of their effects on human health. Particular attention was paid to the carcinogenic effects of these chemicals.

Table 1

Basic chemical hazards in waste incineration plants and their health consequences.

Own study based on [2] and [9]

\begin{tabular}{|c|c|c|c|}
\hline Threat & $\begin{array}{c}\text { Place } \\
\text { of accumulation } \\
\text { in the organism }\end{array}$ & Expected heath impacts & $\begin{array}{c}\text { Proven probability } \\
\text { of occurrence in } \\
\text { humans }\end{array}$ \\
\hline Cadmium & Liver, kidneys & $\begin{array}{l}\text { Adverse effects on the lungs and kidneys } \\
\text { and possible lung, prostate cancer }\end{array}$ & sufficient \\
\hline Chrome & $\begin{array}{l}\text { Liver, spleen, } \\
\text { bone marrow } \\
\text { (only Cr(III), } \\
\text { Cr(VI) is not } \\
\text { accumulated) }\end{array}$ & Skin inflammation, lung cancer & sufficient \\
\hline Nickel & $\begin{array}{l}\text { Liver, kidneys, } \\
\text { bones, lungs }\end{array}$ & $\begin{array}{l}\text { Increased risk of lung and nose cancer, } \\
\text { frequent allergic reactions }\end{array}$ & sufficient \\
\hline Lead & Whole organism & $\begin{array}{l}\text { Cancer of lungs, urinary bladder, kidneys, } \\
\text { gastrointestinal tract }\end{array}$ & insufficient \\
\hline $\begin{array}{c}\text { Dioxins } \\
(\mathrm{PCDD} / \mathrm{Fs})\end{array}$ & $\begin{array}{l}\text { Adipose tissue, } \\
\text { milk }\end{array}$ & $\begin{array}{l}\text { Chloracne, changes in metabolism, } \\
\text { negative impact on the reproductive } \\
\text { abilities, increased risk of cancer }\end{array}$ & no data \\
\hline $\begin{array}{l}\text { Policyclic aromatic } \\
\text { hydrocarbons } \\
\text { (PAHs) }\end{array}$ & $\begin{array}{l}\text { Adipose tissue, } \\
\text { milk }\end{array}$ & Cancer of lungs, skin, urinary bladder & no data \\
\hline
\end{tabular}

Carcinogenesis is one of possible consequences of exposure to the substances listed in the table. According to the report of the Institute for Environment and Health in 1997 [3] it 
has been found, that although there is no significant increase in the incidence of cancer in people working in incineration plants or living in their vicinity in relation to the general population they are exposed, however, to higher levels of these pollutants. The authors of the report did not exclude that the study might not be sensitive enough to detect existing side-effects of exposure to listed chemical substances. The later publication of the Carcinogenity Commission in 2000 includes a similar conclusion: "Any potential cancer risk resulting from residence near municipal solid waste incineration plants are extremely low and probably unmeasurable even using the most modern epidemiological techniques" [4].

Although harmful effects of heavy metals on a human organism and the natural environment seems to be obvious and undeniably confirmed by years of research and experiences, there is still no certainty about the health effects of other substances discussed above - dioxins and polycyclic aromatic hydrocarbons. In the scientific community it is hard to find clear statements and conclusions based on research results, especially those dioxins are emitted during all thermal processes such as: energy production, industrial production, road transport and incineration processes in the municipal sector. There are also natural sources of dioxin emissions - forest fires, volcanic eruptions, electrical discharges. Public concern as well as non-governmental organizations, which proclaim the opinions about undoubted dangers of dioxin and polycyclic aromatic hydrocarbons usually without reference to a specific source, do not help either. In contrast to them Cole et al maintains in his work [5] that the classification of 2,3,7,8-tetrachlorodibenzo-p-dioxin (TCDD) by the IARC as a carcinogen of Group $\mathrm{I}$ is incorrect and that test results do not indicate a carcinogenic effect of this compound on humans in small or high doses.

On the other hand, according to the available literature, it is an undisputed fact that polycyclic aromatic hydrocarbons (PAHs) have carcinogenic properties, and 4 of them are classified by IARC as carcinogens of class I. Particularly dangerous is benzo(a)pyrene, for which there is verified evidence of carcinogenicity in relation to the human body.

In addition to chemical hazards in waste incineration plants there should also be mentioned physical hazards - such as noise and hot microclimate.

Noise, apart from the basic and obvious effects such as: hindering communication, causing distraction at work, increasing the risk of accident and causing discomfort in people exposed to it. The adverse effect of noise on the human body is complex, since it involves direct action: on middle and inner ear and indirect action: on nervous system and psyche as well as the reflex effects on the functioning of other organs. This factor accelerates fatigue, adversely affects the entire body and, above all, can result in damage and even loss of hearing. Indirect effects of damage to the hearing organ among others include: noises in the ears, a feeling of fullness. They can be permanent or reversible. Irreversible effect of noise is the result of partial or total loss of hearing caused by noise impact over many years. The consequence of the partial loss of hearing due to harmful effects of noise are significant disturbances in the assessment of the volume of sound, loss of ability to distinguish pitch and limited ability to determine the direction of sounds [5].

The consequences of the impact of noise on humans include also other than hearing reactions of the body. These include: changes in the cardiovascular system - hypertension, increased heart rate, changes in the gastrointestinal tract - excessive secretion of gastric juice, the tendency to develop gastric ulcer disease, changes in the carbohydrate, fat and 
protein metabolism - a decrease in blood glucose level, a hormonal disorder - stress reactions, quantitative changes in hormones [5].

Working in a hot microclimate requires from the human body an extra effort to maintain thermal equilibrium. For this purpose, the body produces and secretes an increased amount of sweat, which requires heat dissipation by the blood flow to the skin that is cooler than the internal tissue. Hot microclimate has a significant impact on the well-being of working people and their efficiency [6].

The situation of having to work in hot microclimate is called the body heat stress. It causes skin vasodilation, increased sweating and thus the loss of water and mineral salts, the increase in body temperature and heart rate increase. All these irregularities in the functioning of the body lead to illnesses such as heat exhaustion, heat cramps, heat syncope and heat stroke [7].

Another group includes biological hazards which, according to the definition in the Regulation of the Minister of Health [8], are "harmful biological agents which may cause infection, allergy or toxicity and include:

1) cellular microorganisms, including genetically modified;

2) cell-free units capable of replication or of transferring genetic material, including genetically modified;

3) cell cultures;

4) human endoparasites".

The above-mentioned regulation mentions work in waste management plants, which undoubtedly includes waste incineration plants, as belonging to works which expose workers to biological agents [8].

These physical and biological hazards do not raise many social controversies, especially as they relate primarily to the staff of these facilities. They, however, can not be ignored, because incineration plants are not self-serviced installations and the health of people working there deserves the same attention and protection as the health of local residents.

\section{Study of the effects of incineration on the neighborhood}

Studies on the effects of dioxins (PCDD/Fs) for residents in impact areas of waste incineration plants were carried out in recent years in Belgium, France, Portugal and Italy. The authors of papers focused on the existence of the health effects of dioxin emissions to the atmosphere. The works relate to the incineration plants built in the $70 \mathrm{~s}, 80 \mathrm{~s}$ and $90 \mathrm{~s}$, dioxin emissions in that period was not monitored but the level of emissions was roughly estimated for the needs of the carried out simulations (Table 2).

The results of the study are not conclusive, although most of the presented conclusions indicate a clear impact of dioxins on the deterioration of the health condition of the tested population. It should, however, be taken into consideration that the studied facilities were old which were built to meet the demands of a much less restrictive law, tailored to meet less demanding standards of emissions to the atmosphere. These plants over time were modernized and adapted to more and more stringent regulatory requirements or were closed, however, considering the fact that the accumulation of harmful substances in the environment, despite the reduction of emissions to the atmosphere, dioxins accumulated 
during the years of releasing them to the environment could affect for a long time and could freely migrate and be absorbed by people on many levels.

Table 2

Comparison of the area, purpose and scope of research, results and conclusions on the impact of incineration plants on the environment obtained by different authors

\begin{tabular}{|c|c|c|c|c|}
\hline $\begin{array}{c}\text { Area and aim of } \\
\text { the study }\end{array}$ & Range of research & $\begin{array}{c}\text { Emission level } \\
\text { (applicable } \\
\text { emission } \\
\text { standards) }\end{array}$ & Test results & Conclusions \\
\hline $\begin{array}{c}{[10]} \\
\text { Neerlandquarter, } \\
\text { Belgium; } 2 \text { waste } \\
\text { incinerators opened } \\
\text { in the 70-ties and } \\
\text { 80-ties, } \\
\text { Research carried out } \\
\text { due to } \\
\text { complaints of } \\
\text { residents about } \\
\text { numerous health } \\
\text { problems. }\end{array}$ & $\begin{array}{l}\text { Risk assessment based on } \\
\text { chemical, toxicological } \\
\text { research and modeling of } \\
\text { dioxins propagation and } \\
\text { calculating their content in } \\
\text { the soil, food and water; } \\
\text { The level of exposure } \\
\text { converted to equivalent } \\
2,3,7,8 \text {-TCDD; } \\
\text { Blood samples were taken } \\
\text { from } 24 \text { children (10-12 } \\
\text { years old) from the test } \\
\text { area and from the control } \\
\text { group. }\end{array}$ & $\begin{array}{c}\text { Estimated: } \\
\text { from } 18.9 \mathrm{~g} \\
\text { TEQ/year in } \\
1980 \\
\text { up to } 3.1 \mathrm{~g} \\
\text { TEQ/year in } \\
1997 .\end{array}$ & \begin{tabular}{|} 
Soil contamination \\
does not correspond \\
to the substance \\
spreading model. \\
Cytogenetic studies \\
do not show \\
statistically \\
significant \\
differences between \\
the test and control \\
groups.
\end{tabular} & $\begin{array}{c}\text { Incinerators are not the } \\
\text { only source of tested } \\
\text { pathogens. } \\
\text { Children living in the } \\
\text { area in question do not } \\
\text { receive high doses of } \\
\text { genotoxic substances. } \\
\text { Living in the exposed } \\
\text { area does not result in } \\
\text { an increased health } \\
\text { risk. }\end{array}$ \\
\hline \begin{tabular}{|c|} 
[11] \\
Surroundings of 16 \\
waste incineration \\
plants in four \\
administrative units \\
in France; the aim \\
of the study was to \\
assess the impact of \\
long-term exposure \\
to dioxins in the \\
population living \\
near a waste \\
incineration plant. \\
\end{tabular} & $\begin{array}{l}\text { The relationship between } \\
\text { the incidence of cancer and } \\
\text { exposure to } 2,3,7,8 \text {-TCDD, } \\
\text { using national cancer } \\
\text { registries, } \\
25000000 \text { people over the } \\
\text { age of } 14 \text { annually were } \\
\text { examined, } \\
\text { in } 1990-1999, \\
\text { about } 135000 \text { cases of } \\
\text { cancer were found. }\end{array}$ & $\begin{array}{c}\text { Estimated } \\
\text { content in soil in } \\
\text { the years } \\
1972-1984: \\
0.003-0.097 \\
\mu \mathrm{g} / \mathrm{m}^{2} / \text { year. }\end{array}$ & \begin{tabular}{|} 
There is a positive \\
relationship between \\
the exposure to \\
dioxins in the $70^{\prime}$ \\
and $80^{\prime}$ and the \\
incidence of various \\
types of cancer in the \\
years $1990-1999$, the \\
demonstrated \\
exposure is greater \\
for women than for \\
men, although it \\
occurs in both sexes.
\end{tabular} & $\begin{array}{l}\text { Studies are related to } \\
\text { the previous situation } \\
\text { and do not depict the } \\
\text { current problems; } \\
\text { studies do not take into } \\
\text { account individual } \\
\text { factors such as place of } \\
\text { residence, } \\
\text { occupational exposure, } \\
\text { dietary habits. }\end{array}$ \\
\hline $\begin{array}{c}{[12]} \\
\text { Part of the province } \\
\text { of Venice (about } \\
\text { half of its } \\
\text { population), Italy; } \\
\text { aim of the study is } \\
\text { an assessment of the } \\
\text { risk of sarcoma in } \\
\text { relation to } \\
\text { environmental } \\
\text { pollution by dioxins } \\
\text { emitted from waste } \\
\text { incinerators. }\end{array}$ & $\begin{array}{l}\text { The relationship between } \\
\text { the incidence of sarcoma } \\
\text { and exposure to dioxins } \\
\text { emitted from waste } \\
\text { incinerators, } \\
\text { there were used data from } \\
\text { the years 1990-1996 } \\
\text { included in the local } \\
\text { registry of cancer; } 186 \text { out } \\
\text { of } 205 \text { cases of sarcoma } \\
\text { were selected in patients } \\
\text { meeting the criterion of } \\
\text { residence in the study area, } \\
\text { for each patient three } \\
\text { control samples were } \\
\text { taken. }\end{array}$ & $\begin{array}{c}\text { Estimated } \\
\text { emission level to } \\
\text { the atmosphere } \\
\text { in the years } \\
1961-1996: \\
\text { from } 3.0 \cdot 10^{-7}, \\
\text { increased to } \\
1.7 \cdot 10^{-6} \\
\text { (year } 1973 \text { ), and } \\
\text { then was falling } \\
\text { from } 1984 \text { to } \\
1.0 \cdot 10^{-7} \\
\text { in } 1988 .\end{array}$ & \begin{tabular}{|} 
Studies show \\
a significant increase \\
in risk of sarcoma \\
associated with both \\
the level and length \\
of exposure to \\
dioxins, the risk is \\
far greater \\
for women.
\end{tabular} & $\begin{array}{l}\text { The results confirm the } \\
\text { carcinogenic effect of } \\
\text { dioxins on humans, the } \\
\text { results confirm the } \\
\text { thesis about the effects } \\
\text { of exposure to dioxins } \\
\text { on the incidence of } \\
\text { sarcoma in the general } \\
\text { population, with } \\
\text { small concentration of } \\
\text { these pollutants and } \\
\text { long-term exposure. }\end{array}$ \\
\hline
\end{tabular}




\begin{tabular}{|c|c|c|c|c|}
\hline $\begin{array}{c}\text { Area and aim of } \\
\text { the study }\end{array}$ & Range of research & $\begin{array}{c}\text { Emission level } \\
\text { (applicable } \\
\text { emission } \\
\text { standards) } \\
\end{array}$ & Test results & Conclusions \\
\hline $\begin{array}{c}\text { [13] } \\
\text { Area of the city } \\
\text { Besancon, France, } \\
\text { in total about } \\
65 \mathrm{~km}^{2} \text {, waste } \\
\text { incineration plant } \\
\text { opened in } 1971 \text { is } \\
\text { located at a distance } \\
\text { of } 4 \mathrm{~km} \text { from the } \\
\text { city center; aim of } \\
\text { the work is to } \\
\text { determine routes of } \\
\text { dioxins absorption } \\
\text { and the relationship } \\
\text { between the } \\
\text { exposure to low } \\
\text { levels of dioxins } \\
\text { and the incidence of } \\
\text { non-Hodgkin's } \\
\text { lymphoma. } \\
\end{array}$ & $\begin{array}{c}\text { The incidence of non- } \\
\text { Hodgkin's lymphoma in } \\
\text { the years 1980-1995; } \\
\text { control group was selected, } \\
\text { model of average } \\
\text { concentration of dioxins at } \\
\text { ground level in the study } \\
\text { area, using data on dioxin } \\
\text { emissions in 1999, } \\
\text { restoration of previous data } \\
\text { was not possible, the data } \\
\text { were compared with the } \\
\text { incidence of detected cases } \\
\text { of non-Hodgkin's } \\
\text { lymphoma on the modeled } \\
\text { area. }\end{array}$ & $\begin{array}{c}\text { Model: } \\
0.001-0.0016 \\
\mathrm{pg} / \mathrm{m}^{3} \\
\text { Measurements: } \\
16.3 \mathrm{ng} \\
\mathrm{I}-\mathrm{TEQ} / \mathrm{m}^{3} \text { in } \\
\text { waste gases in } \\
1997\end{array}$ & $\begin{array}{c}\text { Studies show } \\
\text { statistically } \\
\text { significant increase } \\
\text { in the risk of non- } \\
\text { Hodgkin's lymphoma } \\
\text { in a group of people } \\
\text { living in the area of } \\
\text { the highest } \\
\text { concentration of } \\
\text { dioxins; This risk is } \\
2,3 \text { times higher } \\
\text { than in the group } \\
\text { living in areas with } \\
\text { the lowest } \\
\text { concentration of } \\
\text { dioxins. }\end{array}$ & $\begin{array}{l}\text { The results confirm the } \\
\text { thesis of an increased } \\
\text { risk of developing non- } \\
\text { Hodgkin's lymphoma } \\
\text { among people living in } \\
\text { the area of waste } \\
\text { incineration plants. }\end{array}$ \\
\hline $\begin{array}{c}{[14]} \\
\text { Portugal, waste } \\
\text { incineration plants } \\
\text { around the city of } \\
\text { Lisbon and on the } \\
\text { island of Madeira. }\end{array}$ & $\begin{array}{c}\text { Measurement of the } \\
\text { content of dioxins in } \\
\text { human milk in two areas } \\
\text { with significantly different } \\
\text { levels of pollution, research } \\
\text { was conducted on } 181 \\
\text { volunteers, over the years } \\
1999 \text { to } 2003 \text {; } \\
\text { The test may not be } \\
\text { representative - the studies } \\
\text { involved only women of } \\
\text { working age who were } \\
\text { breastfeeding. }\end{array}$ & $\begin{array}{l}\text { Content of } \\
\text { PCDD/F in } \\
\text { milk: } \\
\text { average: } \\
\text { 10.6 TEQ pg/g } \\
\text { of fat for the } \\
\text { area of Lisbon, } \\
6.5 \text { TEQ pg/g } \\
\text { for Madeira; } \\
\text { the median } \\
\text { - 10.6 TEQ pg/g } \\
\text { for the area of } \\
\text { Lisbon, } \\
\text { 5.8 TEQ pg/g } \\
\text { for Madeira. }\end{array}$ & $\begin{array}{c}\text { Average } \\
\text { and median values } \\
\text { are almost identical } \\
\text { for the test group and } \\
\text { the control group in } \\
\text { both areas; } \\
\text { Statistical } \\
\text { differences can be } \\
\text { seen when } \\
\text { comparing the two } \\
\text { studied areas - for } \\
\text { women from the area } \\
\text { of Lisbon, content of } \\
\text { PCDD/F } \\
\text { in milk is higher } \\
\text { than in women on } \\
\text { Madeira. }\end{array}$ & $\begin{array}{l}\text { The results indicate no } \\
\text { relationship between } \\
\text { the residence near } \\
\text { waste incineration } \\
\text { plants and elevated } \\
\text { levels of PCDD / F in } \\
\text { milk. There was noted } \\
\text { increased levels of } \\
\text { PCDD/F in women } \\
\text { who live in more } \\
\text { polluted (Lisbon) and } \\
\text { increased level of } \\
\text { PCDD/F along with } \\
\text { the age of volunteers, } \\
\text { which is connected } \\
\text { with the accumulation } \\
\text { of pollutants in the } \\
\text { body for years of } \\
\text { exposure. }\end{array}$ \\
\hline
\end{tabular}

\section{Study of the effects of incineration on employees}

There were also conducted studies of the impact of the same substances on the health of people working in waste incineration plants. These studies were not limited only to the impact of dioxins on human health, there were taken into account also heavy metals, volatile organic compounds. Biological agents, dust or noise in waste incineration plants and their impact on the health of workers were described only in a small number of research works. The assessment of the hazards for people working in these plants was above all based on blood and urine tests, but also on the general health examination, conducted personal surveys on lifestyle, dietary habits, ailments associated with the work, if such were 
observed. The purpose of the comparison of works was primarily the identification of hazards existing in the work environment, assessment of risk associated with them, estimated at various workplaces: administrative and technical or workers - directly connected with the process of waste incineration. An important element of the conducted research was of course health consequences of human exposure to the identified hazards present in the workplace - their reversible and permanent effects, intensity, incidence of observed health effects.

The test results show that it is difficult to tell clearly how big impact on the health of employees has working in exposure to occupational hazards occurring in waste incineration plants. The authors of the Finnish publication on the incineration of municipal waste in Turku indicate that the restructuring of the incineration plant, monitoring the types of waste that go into the combustion chamber and the use of appropriate protection for employees makes it possible to protect people both inside and outside the plant against adverse factors related to the operation of the incineration plant [22]. However, unlike other works, this publication also contains information on biological agents, presence of dust, bioaerosols, endotoxins, noise level. It indicates the specific personal protective equipment to be used by employees in the places, where permissible levels of harmful factors can be exceeded, it does not indicate hazards caused by most frequently mentioned chemicals.

Table 3

Comparison of the area, purpose and scope of research, results, and conclusions on the impact of incineration plants on the health of workers obtained by different authors

\begin{tabular}{|c|c|c|c|c|}
\hline Area of study & Scope of research & $\begin{array}{c}\text { Tested } \\
\text { workplaces }\end{array}$ & Results & Conclusions \\
\hline $\begin{array}{c}{[15]} \\
\text { Japan, three and } \\
\text { six municipal } \\
\text { waste } \\
\text { incineration } \\
\text { plants }\end{array}$ & $\begin{array}{c}\text { Exposure to dust } \\
\text { containing dioxins } \\
\text { (dioxins concentration } \\
\text { in the dust), test of } \\
\text { concentration of } \\
\text { dioxins in blood and } \\
\text { plasma. }\end{array}$ & \begin{tabular}{|} 
Works performed \\
periodically, eg \\
cleaning of cooling \\
towers, \\
electrostatic \\
precipitators \\
and fabric filters. \\
Permanent works: \\
weighing the \\
waste, operating \\
cranes among \\
others.
\end{tabular} & $\begin{array}{c}\text { Depending on the } \\
\text { type of works, } \\
\text { average } 1.7 \mathrm{pg} \\
\mathrm{TEQ} / \mathrm{m}^{3} \text { to } 81000 \\
\mathrm{pg} \mathrm{TEQ} / \mathrm{m}^{3} \text { in dust. } \\
\text { Average from } 46 \mathrm{pg} \\
\mathrm{TEQ} / \mathrm{g} \text { of fat to } 346 \\
\mathrm{pg} \mathrm{TEQ} / \mathrm{g} \text { of fat in } \\
\text { blood. Average } 23 \text { to } \\
35 \mathrm{pg} \mathrm{TEQ} / \mathrm{g} \text { of fat } \\
\text { in plasma. }\end{array}$ & $\begin{array}{l}\text { Special attention should be } \\
\text { paid to employees who have } \\
\text { contact with slag and dust, as } \\
\text { the concentration of dioxins } \\
\text { in their blood were highest. } \\
\text { Concentrations of dioxins in } \\
\text { plasma were comparable to } \\
\text { concentrations in the control } \\
\text { group. }\end{array}$ \\
\hline $\begin{array}{c}{[16]} \\
\text { Germany, } \\
\text { study in two } \\
\text { municipal waste } \\
\text { incineration } \\
\text { plants - old and } \\
\text { new }\end{array}$ & $\begin{array}{c}\text { Study of concentration } \\
\text { of } \\
10 \text { major PCDD } \\
\text { and PCDFs in blood, } \\
\text { in a group of } \\
\text { employees of the old } \\
\text { and new incineration } \\
\text { plants and in the } \\
\text { control group, the } \\
\text { concentration of } 10 \\
\text { major PCDD } \\
\text { and PCDF in slag } \\
\text { and dust from the old } \\
\text { incinerator. }\end{array}$ & $\begin{array}{c}\text { Locksmiths, who } \\
\text { are most exposed } \\
\text { to the inhalation of } \\
\text { dust from waste } \\
\text { incineration. }\end{array}$ & $\begin{array}{c}\text { Average TEQ } \\
\text { (ppt, fat): } \\
\text { old incineration } \\
\text { plant: } 24.3-66.1 \\
\text { including } \\
\text { locksmiths: } \\
\text { 38.5-66.1 } \\
\text { new incineration } \\
\text { plant: } \\
\text { 20.5-63.5 } \\
\text { control group: } \\
\text { 17.3-76.4. }\end{array}$ & $\begin{array}{l}\text { There are no significant } \\
\text { differences in exposure } \\
\text { between workers of the new } \\
\text { incineration plant and the } \\
\text { control group, in comparison } \\
\text { with the control group in the } \\
\text { employees of the old } \\
\text { incineration plant there was } \\
\text { a significant increase in the } \\
\text { concentration of octaCDD, } \\
\text { hexaCDF, heptaCDF and the } \\
\text { total concentration of PCDD } \\
\text { and PCDF. }\end{array}$ \\
\hline
\end{tabular}




\begin{tabular}{|c|c|c|c|c|}
\hline Area of study & Scope of research & $\begin{array}{c}\text { Tested } \\
\text { workplaces }\end{array}$ & Results & Conclusions \\
\hline $\begin{array}{c}\text { [17] } \\
\text { Taiwan, } \\
\text { temporary } \\
\text { workers } \\
\text { in four different } \\
\text { waste } \\
\text { incineration } \\
\text { plants }\end{array}$ & $\begin{array}{l}\text { The concentration of } \\
\text { PCDD and PCDF in } \\
\text { the plasma of } \\
\text { temporary workers, } \\
\text { carrying out cleaning } \\
\text { and maintenance } \\
\text { works on the area of } \\
\text { different incineration } \\
\text { plants, before and } \\
\text { after one month's } \\
\text { work in the } \\
\text { incineration plant. }\end{array}$ & $\begin{array}{c}\text { Workers cleaning } \\
\text { and repairing } \\
\text { equipment in the } \\
\text { area of furnaces, } \\
\text { waste gas cleaning } \\
\text { devices. }\end{array}$ & \begin{tabular}{|} 
Before starting work: \\
15.7 and $24.1 \mathrm{pg}$ \\
TEQ/g of fat \\
After one month: \\
19.6 and $27.5 \mathrm{pg}$ \\
TEQ/g of fat.
\end{tabular} & $\begin{array}{l}\text { The level of the tested } \\
\text { substances was significantly } \\
\text { higher after than before } \\
\text { starting work, especially in } \\
\text { those working in exposure to } \\
\text { dust, there was no difference } \\
\text { in concentration between the } \\
\text { workers and management } \\
\text { staff, higher concentration of } \\
\text { the substance has been } \\
\text { observed in persons engaged } \\
\text { in this type of work earlier } \\
\text { than those working in the } \\
\text { plant for the first time. }\end{array}$ \\
\hline $\begin{array}{c}{[18]} \\
\text { Taiwan, three } \\
\text { municipal waste } \\
\text { incineration } \\
\text { plants opened in } \\
\text { the 90s }\end{array}$ & $\begin{array}{l}\text { Study of PCDD and } \\
\text { PCDF concentrations } \\
\text { in the air and in blood } \\
\text { of randomly selected } \\
\text { employees of the } \\
\text { incineration plant. }\end{array}$ & $\begin{array}{l}\text { Air measurement - } \\
4 \text { points in each } \\
\text { incineration plant; } \\
\text { Workers for blood } \\
\text { tests were chosen } \\
\text { randomly, } \\
\text { from different } \\
\text { jobs, both workers } \\
\text { and administrative } \\
\text { staff. }\end{array}$ & \begin{tabular}{|} 
The geometric mean \\
of concentration In \\
blood: 14.615 .8 and \\
$19.1 \mathrm{pg}$ TEQ/ g of \\
fat in subsequent \\
incineration plants; \\
Average \\
concentrations in the \\
air: \\
$0.008-3.01 \mathrm{pg} / \mathrm{m}^{3}$.
\end{tabular} & $\begin{array}{l}\text { The results showed no } \\
\text { correlation between the time } \\
\text { of employment and the } \\
\text { concentration of PCDD/F in } \\
\text { the blood of workers, there } \\
\text { was no correlation between } \\
\text { time spent in individual } \\
\text { departments of the plants and } \\
\text { the level of tested substances } \\
\text { in the blood. }\end{array}$ \\
\hline $\begin{array}{c}\text { [19] } \\
\text { Spain, } \\
\text { hazardous waste } \\
\text { incineration } \\
\text { pant opened } \\
\text { in } 1999\end{array}$ & $\begin{array}{c}\text { Plasma tests: HCB, } \\
\text { PCBs, PCDD, PCDF } \\
\text { Urine tests: DCPS, } \\
\text { TCPs, PCP, } \\
\text { 1-HP and Cd, Cr, Ni, } \\
\text { V. Tests of the content } \\
\text { of Be, Mn, } \mathrm{Hg} \text { and Pb } \\
\text { in blood; study carried } \\
\text { out in two consecutive } \\
\text { years of incineration } \\
\text { plant operation. }\end{array}$ & $\begin{array}{c}\text { Employees divided } \\
\text { into three groups: } \\
\text { plant workers, } \\
\text { laboratory staff } \\
\text { and administrative } \\
\text { staff. }\end{array}$ & $\begin{array}{c}\text { Level of PCDD/F in } \\
\text { plasma } \\
\text { calculated as I-TEQ } \\
\text { pg /g of fat): } \\
\text { Year 1999-26.7 } \\
\text { Year 2000-16.9 } \\
\text { Year 2001 - 10.0 } \\
\text { Year 2002-10.3 }\end{array}$ & $\begin{array}{l}\text { There were no differences } \\
\text { between the concentrations of } \\
\text { the tested substances in the } \\
\text { workers of the incineration } \\
\text { plant compared with a group } \\
\text { not exposed to these } \\
\text { pollutants, no differences } \\
\text { were noted in the } \\
\text { concentration of tested } \\
\text { pollutants between individual } \\
\text { professional groups in the } \\
\text { plant. }\end{array}$ \\
\hline $\begin{array}{c}{[20]} \\
\text { France, two } \\
\text { municipal waste } \\
\text { incineration } \\
\text { plants }\end{array}$ & $\begin{array}{c}\text { Examination of lung } \\
\text { function by means of } \\
\text { a spirometer in } \\
\text { workers exposed to } \\
\text { airborne pollutants, } \\
\text { during the annual } \\
\text { periodic examination, } \\
\text { for the next three } \\
\text { years; the study of air } \\
\text { samples for the } \\
\text { presence of airborne } \\
\text { pollutants. }\end{array}$ & $\begin{array}{l}\text { Employees of the } \\
\text { incineration plant } \\
\text { excluding white } \\
\text { collar workers. }\end{array}$ & $\begin{array}{c}\text { Vital capacity of } \\
\text { lungs (average } \\
\text { respectively } \\
\text { in the first and third } \\
\text { year): } \\
\text { Group I: } \\
\text { test: } 97.8 \%, \\
\text { control: } 99.4 \% \\
\text { Group III: } \\
\text { test: } 95.6 \%, \\
\text { control: } 97.0 \%\end{array}$ & $\begin{array}{l}\text { No relationship was noted } \\
\text { between exposure to airborne } \\
\text { pollutants and changes in } \\
\text { lung function in workers of } \\
\text { incineration plant; there was } \\
\text { observed a slight weakening } \\
\text { of lung function, which may } \\
\text { suggest the presence of } \\
\text { obstructive lung disease, but } \\
\text { this is not confirmed. } \\
\text { There are no significant } \\
\text { differences in the test results } \\
\text { between the test group and } \\
\text { the control group. }\end{array}$ \\
\hline
\end{tabular}




\begin{tabular}{|c|c|c|c|c|}
\hline Area of study & Scope of research & $\begin{array}{c}\text { Tested } \\
\text { workplaces }\end{array}$ & Results & Conclusions \\
\hline $\begin{array}{c}{[21]} \\
\text { France, two } \\
\text { municipal waste } \\
\text { incineration } \\
\text { plants, one of } \\
\text { them also for } \\
\text { medical waste }\end{array}$ & $\begin{array}{l}\text { The questionnaire } \\
\text { specifying dietary } \\
\text { habits, lifestyle, } \\
\text { physical examination } \\
\text { conducted by one } \\
\text { doctor, tests of lead } \\
\text { levels in blood, } \\
\text { liver enzyme test, } \\
\text { spirometry test. }\end{array}$ & $\begin{array}{l}\text { Employees were } \\
\text { divided due to the } \\
\text { scope of duties, } \\
\text { with the exception } \\
\text { of administrative } \\
\text { staff. }\end{array}$ & $\begin{array}{c}\text { Vital capacity of } \\
\text { lungs of individual } \\
\text { groups of employees } \\
\text { (in [\%]): } \\
\text { Group: control: } \\
98.9 \pm 12.0 \\
\text { Crane operators: } \\
102.3 \pm 15.6 \\
\text { Furnace operators: } \\
95.4 \pm 11.8 \\
\text { Service staff: } \\
94.8 \pm 18.6\end{array}$ & $\begin{array}{l}\text { Significantly more symptoms } \\
\text { of irritation of skin and } \\
\text { mucous membranes in } \\
\text { a group working in the } \\
\text { incineration plant than } \\
\text { in the control group, } \\
\text { in the exposed group higher } \\
\text { incidence of cough; } \\
\text { People in the test group } \\
\text { showed lower respiratory } \\
\text { performance than the control } \\
\text { group, there was confirmed } \\
\text { a convergence between lower } \\
\text { respiratory performance and } \\
\text { length of employment in the } \\
\text { incineration plant. } \\
\text { Incineration plant workers } \\
\text { reported more accidental } \\
\text { events and benefit from } \\
\text { longer sick leaves than those } \\
\text { in the control group. }\end{array}$ \\
\hline
\end{tabular}

The factors on which most research focus are the chemicals released as a by-product of the combustion reaction, mainly dioxins and heavy metals. Dioxins cause the greatest concern, their impact on human health and life is least known, least sure are effects of these factors on health and life and their quantities present in the environment needed to elicit these effects. Most of the authors point to the need for further observations in the directions indicated by them, because achievements to date do not solve the issue of health risk to workers of the incineration plants, they may be only a guideline indicating the type of problems faced at present and in future by workers exposed to those harmful factors.

\section{Conclusion}

Investing in the construction of waste incineration plants in Poland has a specific goal, apart from the need to meet the legal requirements under the threat of financial penalties from the European Community. Such a change in the entire waste management system is guided by the need to improve the quality of the environment or at least a desire for non-deterioration of its condition. An important issue is if, by changing the present method of dealing with waste, some harmful for environment substances are replaced by other equally adverse, if side effects of the already functioning system are smaller or greater than those of the system that needs to be implemented. For example, by analyzing changes in the waste management system in New York [23] it was stated that living near a landfill causes more than 5 times higher risk of developing cancer and other serious diseases than living in the area of a waste incineration plant. However, this problem can not be solved theorizing, research carried out so far in foreign facilities does not allow for an unambiguous transfer of conclusions to the current situation. Therefore, there is a justified need for a reliable, systematic research in the existing waste incineration plants in our country. So far in Poland there was no motivation to conduct studies in this field, now they are motivated by the health of workers, local residents and the condition of natural environment. It is necessary 
to determine whether the current regulations are a sufficient protection against potentially harmful effects of waste incineration plants for workers and people living in the immediate surroundings. The results of the research can serve as a key argument in the debate on the expediency of the construction of waste incineration plants in Poland and the discussion of possible risks that these plants pose to people and the environment.

\section{References}

[1] Dyrektywa Parlamentu Europejskiego i Rady 2008/98/WE z dnia 19 listopada 2008 r. w sprawie odpadów oraz uchylająca niektóre dyrektywy. Dziennik Urzędowy Unii Europejskiej L 312/4.

[2] MRC Institute for Environment and Health. Health effects of waste combustion products, 1997.

[3] UK Medicines and Healthcare Products Regulatory Agency - Komisja ds. Rakotwórczości 2000 „Występowania raka w pobliżu komunalnych spalarni odpadów stałych w Wielkiej Brytanii” - protokół COC/00/S1 - marzec 2000 .

[4] Cole P, Trchopoulos D, Pastides H, Starr T, Mandel JS. Dioxin and cancers: a critical review. Regulatory Toxicol and Pharmacol. 2003;38:378-388. DOI: 10.1016/j.yrtph.2003.08.002.

[5] Indulski JA, editor. Higiena pracy Tom 2, Łódź: Instytut Medycyny Pracy im. Prof. J Nofera; 1999.

[6] Bryła R. Bezpieczeństwo i Higiena Pracy. Katowice: Wyd. ELAMED; 2011.

[7] Indulski JA, editor. Higiena pracy Tom 1, Łódź: Instytut Medycyny Pracy im. Prof. J Nofera; 1999.

[8] Rozporządzenia Ministra Zdrowia z dnia 22 kwietnia 2005 roku w sprawie szkodliwych czynników biologicznych dla zdrowia w środowisku pracy oraz ochrony zdrowia pracowników zawodowo narażonych na te czynniki.

[9] Franchini M, Rial M, Buiatti E, Bianchi F. Health effects of exposure to waste incinerator emissions: a review of epidemiological studies. Ann Ist Super Sanità. 2004;40(1):101-115.

[10] Nouwen J, Cornelis C, De Fré R, Wevers M, Viaene P, Mensink C, et al. Health risk assessment of dioxin emission from municipal waste incinerators: The Neerlandquarter (Wilrijk Belgium). Chemosphere. 2001;43:909-923.

[11] Fabre P, Daniau C, de Crouy-Chanel P, Goria S, Paez-Jimenez A, Colonna M, et al. Dioxin exposure and cancer incidence in vicinity to municipal solid waste incinerators in France. Organohalogen Compounds. 2007;69:1021-1025.

[12] Zambon P, Ricci P, Bovo E, Casula A, Gattolin M, Fiore AR, et al. Sarcoma risk and dioxin emissions from incinerators and industrial plants: a population-based case-control study (Italy). Environ Health. 2007;6(19):1-10. DOI: 10.1186/1476-069X-6-19.

[13] Floret N, Mauny F, Challier B, Arveux P, Cahn J, Viel JF. Dioxin emissions from a solid waste incinerator and risk of Non-Hodgkin lymphoma. Epidemiology. 2003;14(4):392-8. DOI: 10.1016/j.envint.2010.11.009.

[14] Fátima-Reis M, Sampaio C, Aguiar P, Maurício-Melim J, Pereira-Miguel J, Päpke O. Biomonitoring of $\mathrm{PCDD} / \mathrm{Fs}$ in populations living near Portuguese solid waste incinerators: Levels in human milk. Chemosphere. 2007;67(9):S231-S237. DOI: 10.1016/j.chemosphere.2006.05.103.

[15] Kumagai S, Koda S, Oda H. Exposure evaluation of dioxins in municipal waste incinerator workers. Industrial Health. 2003;41:167-174. DOI: 10.2486/indhealth.41.167.

[16] Schecter A, Papke O, Ball M, Lis A, Brandt-Rauf P. Dioxin concentrations in the blood of workers at municipal waste incinerators. Occupational and Environ Medicine. 1995;52:385-387. DOI: 10.1136/oem.52.6.385.

[17] Shih TS, Chen HL, Wu YL, Lin YC, Lee CC. Exposure assessment of polychlorinated dibenzo-p-dioxins and dibenzofurans (PCDD/Fs) in temporary municipal-waste-incinerator maintenance workers before and after annual maintenance. Chemosphere. 2006;64:1444-1449. DOI: 10.1016/j.chemosphere.2006.01.014.

[18] Hu W, Chang-Chien GP, Chan CC. PCDD/Fs levels in indoor environments and blood of workers of three municipal waste incinerators in Taiwan. Chemosphere. 2004;55:611-620. DOI: 10.1016/j.chemosphere.2003.10.057.

[19] Carmen AM, Domingoa AL, Domingoa H, Corbella J. Monitoring internal exposure to metals and organic substances in workers at a hazardous waste incinerator after 3 years of operation. Toxicology Letters. 2003;146:83-91. DOI: 10.1016/j.toxlet.2003.09.003.

[20] Charbotel B, Hours M, Perdrix A, Anzivino-Viricel L, Bergeret A. Respiratory function among waste incinerator workers. Int Arch Occup Environ Health. 2005;78:65-70. DOI: 10.1007/s00420-004-0557-7. 
[21] Hours M, Anzivino-Viricel L, Maitre A, Perdrix A, Perrodin Y, Charbotel B, et al. Morbidity among municipal waste incinerator workers: a cross-sectional study. Int Arch Occup Environ Health. 2003;76:467-472.

[22] Tolvanen O, Hanninen K. Occupational hygiene in a waste incineration plant. Waste Manage. 2005;25:519-529. DOI: 10.1016/j.wasman.2005.01.010.

[23] Moy P, Krishnan N, Ulloa P, Cohen S, Brandt-Raul PW. Options form management of municipal solid waste in New York City: a preliminary comparison of health risk and policy implications. J Environ Manage. 2008;87:73-79. DOI: 10.1016/j.jenvman.2007.01.032.

\title{
ODDZIAEYWANIE SPALARNI ODPADÓW NA LUDZI I ŚRODOWISKO
}

\author{
Wydział Inżynierii Procesowej i Ochrony Środowiska, Politechnika Łódzka
}

\begin{abstract}
Abstrakt: Poruszono tematykę związaną z oddziaływaniem spalarni odpadów na zdrowie osób w nich zatrudnionych oraz środowisko naturalne. Celem pracy jest dokonanie szerokiego przeglądu istniejącego piśmiennictwa w tym zakresie. Dokonano go, korzystając z licznych, opisanych w literaturze, wyników badań wykonanych w wielu spalarniach odpadów zarówno w Europie, jak i na świecie. W analizowanych pracach poruszano tematykę zagrożeń na stanowiskach pracy, zarówno administracyjnych, jak również bezpośrednio związanych z procesem termicznego przetwarzania odpadów. Zagrożenia te wynikają między innymi z emisji do atmosfery wielu zanieczyszczeń, w tym przede wszystkim polichlorowanych dibenzo-p-dioksyn i polichlorowanych dibenzofuranów, metali ciężkich oraz niektórych lotnych związków organicznych. Wyniki badań stanowić będą istotny argument w dyskusji na ewentualnymi zagrożeniami dla ludzi i środowiska stwarzanymi przez spalarnie odpadów i celowości ich budowy w Polsce.
\end{abstract}

Słowa kluczowe: spalanie odpadów, odzysk energii z odpadów, oddziaływanie na środowisko, bezpieczeństwo przemysłowe i higiena pracy 